Voces/Escrituras.

La poesía europea

de fines del siglo

$X I X$ : una nueva

\title{
mirada
}

SANDRo Abate y OtRos

Ediuns

Bahía Blanca, 2005

\section{La poesía vista desde el sur}

\author{
Nicolás Gallego Livigni •
}

UNPSJB

Voces/Escrituras, recientemente publicado por la Editorial de la Universidad Nacional del Sur, es un volumen compuesto por varios estudios vinculados con el proyecto de investigación titulado "La poesía europea de fines del siglo XIX: una nueva mirada”, dirigido desde hace tres años por el Dr. Sandro Abate. Se trata de la primera compilación de trabajos de este equipo, integrado por investigadores del sur del país, que aborda la centenaria lírica europea desde una perspectiva que apunta a considerarla en el marco comparatista, sin excluir las posibilidades de una visión de conjunto que tome en cuenta nuestra condición latinoamericana.

El libro, precedido por una Introducción a cargo de Abate, se compone de varios capítulos, a saber: "Baudelaire, Yeats y las deconstrucciones de la poesía" (David Fiel), "Una temporada en el infierno: la invención de lo inhumano" (Liliana Griskan), "Intimidad de Alma: un enlace entre ideal, belleza y arte" (Laura Quadrelli), "El despegue rapaz de Los aguiluchos: unas páginas rezagadas de Leopoldo Marechal" (Mariel Rabasa), "Il simbolismo visionario di Giorvanni Pascoli" (Francesco Quatela), y "D’Annunzio y la lírica europea de finales del siglo XIX: el caso de L'Isottèo" (Sandro Abate).

Quiero, por mi parte, limitarme a señalar algunas razones por las cuales creo que este libro sobre "escrituras" literarias del siglo XIX vale la pena ser leído hoy. Un libro que nos pone en diálogo con ciertas "voces”, por ejemplo la de Rimbaud o Baudelaire, cuyo modo y espacio de articulación ha sido la escritura. Por lo tanto, si bien en tanto "voces" hablan desde tiempos y geografías distantes para nosotros, en tanto "escrituras" permanecen en la restancia de sus marcas y continúan solicitando nuestras categorías de interpretación, haciendo temblar nuestros juicios, prejuicios y conceptos sobre la literatura y, en general, sobre nuestra propia existencia. Por eso creo que éste es, ante todo, un libro de "escrituras" sobre "escrituras"; las "voces", en cambio, sólo pueden ser las nuestras, y pronto serán olvidadas.

Ante todo, el libro tiene interés, sencillamente, porque arroja luz sobre las obras de Arthur Rimbaud, Charles Baudelaire, W. B. Yeats, nuestro entrañable Leopoldo Marechal, Manuel Machado, Giovanni Pascoli y Gabriele d'Annunzio. Aquí se piensa la singularidad y la especificidad de sus manifestaciones y las múltiples experiencias e ideas cifradas en ellas, legibles en ellas, supuestas en ellas. Esto solo podría bastar para justificar su lectura. Pero recordemos que éstas no son "voces",

- Licenciado en Filosofía egresado de la Universidad de Buenos Aires. Se desempeña como profesor en la Universidad Nacional de la Patagonia San Juan Bosco, sede Trelew. 
sino escrituras arriesgadas en nombres propios sobre otras escrituras signadas también por otros "nombres propios"; lo cual, dicho (y oído) en francés (nom propre), como mostró Derrida, desata el juego de la desapropiación de la escritura con respecto a su autor. El "nombre propio" es oído también como "no propio" y la escritura, entonces, aunque firmada por su "autor", se nos entrega, sin embargo, desapropiada de la autoridad de una subjetividad logo-fálica que pudiese reclamar la posesión de las significaciones: la escritura así desapropiada nos sale al encuentro desguarecida, expósita, desamparada, abierta, diferida... Y así nos reclama como lectores que deberemos entonces practicar lo propio de nuestra lectura: acaso, otras escrituras, como las ofrecidas en este libro. Llegados a este punto se advierte que esta es la reseña, no de un libro, sino de un espacio de encrucijadas de caminos que involucran nuestros propios pies, el topos donde aparecen desplegadas, en su orfandad, las huellas escritas de ciertos sentidos que necesitan de nuestro propio andar como lectores para llegar a ser palabra que nos hable.

Pero, además, el libro interesa porque cada uno de sus capítulos intenta repensar el ejercicio mismo de la poetización, repensar la práctica literaria. Y esto en íntima relación con un contexto histórico-cultural signado por el anuncio nietzscheano de la muerte de un dios que si bien, parece, no ha terminado de morir para nosotros, sin embargo su inocultable agonía continúa siendo (creo) el sustrato de nuestro agonismo actual, de nuestros padecimientos y dificultades a la hora de dotar de sentido a la experiencia humana. Es decir, entiendo que todavía nuestra situación cultural, histórica, está signada por formas (aunque nuevas) de decadentismo, nihilismo y, como he dicho, por la agonía de un sentido que convalece. Pérdida del fundamento, discursos abismados en el vacío de sentido, posturas, imposturas, malestares, conciencias fracturadas, balbuceos, enmudecimientos: el ser en el lenguaje como en su casa, pero la casa en ruinas y el "ser" impronunciable, indecible sin rubor. Nuestro agôn, nuestro agonismo, nuestra lucha como escritores, lectores, artistas, actores en sociedad, sigue dándose sobre el fondo de la "muerte de dios" anunciada en el siglo XIX, la pérdida del sentido o el fundamento último de la existencia, y puede comprenderse como una lucha, entre hombres, por la restitución permanente del sentido o los sentidos de la experiencia humana. De este modo, encuentro que en Voces/Escrituras se piensan las obras líricas y la práctica literaria en relación con el contexto histórico cultural de fines del siglo XIX pero, como he querido insinuar, nuestro propio contexto histórico conserva irresueltas tensiones y malestares que afloraron en aquella época cercana. Por lo tanto, en este sentido, la lectura de este libro nos permite releernos en él.

Es oportuno señalar, además, que en este libro el pensamiento de las obras literarias y del contexto histórico-cultural finisecular resulta ser, en un sentido laxo, dialéctico. Quiero decir que aquí, en grado variable en cada artículo, se piensa la relación entre "texto" y "contexto" (códigos estéticos o líricos precisos y contexto histórico cultural) en mutua determinación; es decir, se piensa cómo cada uno de los polos de esta relación explica y además contribuye a configurar el otro. Siendo esta imbricación dialéctica, desde luego, sólo perceptible para un pensamiento que remonta su vuelo al caer el sol, como el búho de Minerva hegelieano. Es decir, sin duda, este libro intenta aprovechar las posibilidades de comprensión que nos ofrece la perspectiva histórica que implica cargar ya sobre nuestras lastimadas espaldas las heridas y las desilusiones que nos legó el doloroso siglo XX.

Dos últimas razones del valor de esta publicación. Primeramente, encuentro que 
la ausencia de un centro epistémico rígido para la elaboración de estos artículos críticos (o bien, la presencia de un suelo epistemológico en proceso de definición y esclarecimiento de sus límites y posibilidades) acaba siendo motivo de seducción para los lectores. Dicha ausencia de un centro epistémico rígido o altamente elaborado produce un libre juego de fuerzas relacionales entre los diversos artículos, como planetas moviéndose sin referencia a un astro fijo. $\mathrm{Al}$ no primar un marco epistemológico rígido que venga a determinar desde fuera la producción de significaciones de los diferentes artículos y sus relaciones entre sí, se abre un libre juego de fuerzas relacionales entre los capítulos del libro; "libre" justamente por su grado de indeterminación a priori. Pero justamente este fenómeno, propio de una investigación en proceso, acaba por motivar un lector protagonista, un lector que asuma en la práctica de su lectura un rol activo como espacio de encuentro y de conflicto para aquellas fuerzas relacionales. El libro, así, indefectiblemente, nos implica.

Finalmente, encuentro que en Voces/Escrituras se arriesga pensamiento, es decir, en cada artículo pueden hallarse significaciones en riesgo. Ciertamente los autores de este libro no entienden su actividad de investigadores según su modalidad más decepcionante, a saber: la recolección de datos o informaciones y su posterior organización en esquemas prediseñados; antes bien, dentro de los límites y condicionamientos de cada artículo, es evidente que prima la voluntad de producir sentidos, significaciones.

Quizás estos “sentidos”, resulten para nosotros más cercanos de lo que podríamos colegir con la sola lectura del título del volumen. Quizás, también nosotros, aprovechemos esta "nueva mirada" sobre la poesía finisecular del siglo XIX. Porque, quizá, también nosotros, lectores y escritores del 2006, somos finiseculares y, en cierto modo, inconscientes epígonos de aquellas poéticas. Acaso, lo asumamos o no, somos legítimos herederos de la agonía de un dios que todavía nos hace temblar desde aquellas escrituras poéticas. En su Zaratustra, escrito durante la década de 1880, anota Nietzsche: "Peligroso es ser heredero". Considero que la lectura de Voces/Escrituras nos propone asumir -y asumirnos en- el peligro de nuestra propia herencia. Resta la escritura. 